\title{
PENINGKATAN MINAT BELAJAR IPS SEJARAH DENGAN MENGGUNAKAN STRATEGI PEMBELAJARAN THE POWER OF TWO PADA SISWA KELAS VII B MTS NEGERI KEMBANGSAWIT TAHUN PELAJARAN 2010/2011
}

\author{
Anjar Mukti Wibowo \\ Wiwik Lailatur Rodliyah *)
}

\begin{abstract}
Abstrak
Penelitian ini bertujuan untuk mengetahui minat belajar siswa dan peningkatan keaktifan serta prestasi siswa pada pelajaran IPS Sejarah dengan menggunakan strategi pembelajaran The Power Of Two Subjek penelitian ini adalah siswa kelas VII B MTs Negeri Kembangsawit Tahun Pelajaran 2010/2011 yang berjumlah 37 siswa, yang terdiri dari 22 siswa lakilaki dan 15 siswa perempuan.

Penelitian ini merupakan Penelitian Tindakan Kelas yang dirancang dalam 2 siklus, setiap siklus terdiri dari 4 tahapan, yaitu perencanaan, pelaksanaan, pengamatan, dan refleksi. Pengumpulan data menggunakan metode angket, observasi dan tes. Data yang diperoleh adalah data angket minat belajar siswa, keaktifan siswa serta prestasi belajar siswa.

Berdasarkan data yang diperoleh, diketahui presentase hasil angket minat belajar siswa pada IPS Sejarah siklus I adalah 46\% meningkat pada siklus II menjadi 92\%, begitu pula dengan keaktifan siswa yang mengalami peningkatan, pada siklus I presentase keaktifan siswa $41 \%$ naik pada siklus II menjadi $84 \%$, dan prestasi belajar siswa pra siklus 35\% meningkat pada siklus I 46\% dan pada siklus II menjadi $92 \%$.
\end{abstract}

Kata kunci: Strategi Pembelajaran The Power Of Two, Minat Belajar, IPS Sejarah

\section{Pendahuluan}

Minat seperti yang dipahami orang selama ini dapat mempengaruhi kualitas pencapain hasil belajar siswa dalam bidang-bidang tertentu. Seorang siswa yang menaruh minat besar terhadap suatu mata pelajaran akan memusatkan perhatiaanya lebih banyak dari pada siswa lainya. Kemudian, karena pemusatan perhatian yang intensif terhadap materi itulah yang memungkinkan siswa tadi untuk belajar lebih giat, dan akhirnya mencapai

* Anjar Mukti Wibowo, Dosen Mahasiswa Pendidikan Sejarah IKP PGRI MADIUN

Wiwik Lailatur Rodliyah, Mahasiswa Pendidikan Sejarah IKP PGRI MADIUN 
prestasi yang diinginkan. (Muhibbin Syah, 1999:136-137)

IImu sejarah merupakan dasar semua disiplin ilmu yang termasuk dalam kategori ilmu-ilmu sosial dan humaniora. Sejarah juga merupakan dasar kajian filsafat, ilmu politik, ilmu ekonomi, dan bahkan seni dan agama atau relegi. Maka tidak diragukan lagi bahwa sejarah merupakan ilmu pengetahuan yang sangat diperlukan untuk pendidikan manusia seutuhnya. (Kochhar terjemah Purwanta, Yovita Hardiwati, 2008:1).

Metode pembelajaran sejarah yang baik memiliki karakteristik sebagai berikut: membangkitkan minat yang besar dalam benak siswa, menanamkan nilai-nilai yang diperlukan, perilaku yang pantas, dan kebiasaan kerja diantara siswa, mengubah penekanannya dari pembelajaran secara lisan dan penghafalan ke pembelajaran melalui situasi yang bertujuan konkret dan nyata, mengembangkan eksperimen guru dalam situasi kelas yang sesungguhnya, memiliki keleluasaan untuk aktivitas dan partisipasi para siswa, menstimulasi keinginan untuk melakukan studi dan eksplorasi lebih lanjut, membangkitkan minat tentang materi dan teknik yang digunakan oleh para sejarawan agar siswa dapat memahami bagaimana para sejarawan menulis sejarah. (Kochhar terjemah Purwanta \& Hardiwati, 2008: 286-287).

Hasil observasi pada kelas VIIB MTsN Kembangsawit menunjukkan bahwa siswa kurang berminat pada mata pelajaran IPS Sejarah. Ini dapat dilihat dari hasil belajar siswa pada ujian harian I semester genap hanya mencapai $35 \%$, sedangkan KKM pelajaran IPS Sejarah pada MTsN Kembangsawit adalah 60, dari 37 siswa yang mendapatkan nilai sesuai dengan KKM adalah 12 siswa sedangkan 25 lainya mendapatkan nilai dibawah KKM. Salah satu penyebab kurang berminatnya siswa aktif dalam pembelajaran IPS Sejarah adalah metode pengajaran yang digunakan guru kurang bervariasi, sehingga kurang menarik siswa untuk aktif didalamnya. Metode yang digunakan guru bersifat konvensional yaitu menggunakan metode ceramah dan diskusi dalam kelompok besar yang tidak divariasikan dengan metode-metode lainya. Pada dasarnya diskusi juga dapat mengaktifkan siswa, tetapi jika tidak divariasikan dengan metode lain dan jumlah anggota dalam diskusi cukup banyak, maka dapat membuat siswa lain hanya berpangku tangan pada siswa yang lebih pandai dalam kelompoknya, hal lain yang terkadang terjadi hanya ngobrol masalah lain diluar mata pelajaran.

Pembelajaran aktif menggunakan strategi pembelajaran The Power Of Two atau kekuatan dua orang adalah strategi pembelajaran dengan pemberian tugas belajar yang dilakukan dalam kelompok kecil yang terdiri dari 2 siswa. Dukungan sesama siswa dan keragaman pendapat, pengetahuan serta ketrampilan mereka akan membantu menjadikan belajar bersama sebagai bagian berharga dari iklim belajar di kelas siswa. Aktivitas ini digunakan untuk meningkatkan pembelajaran dan menegaskan manfaat dari sinergi, bahwa dua kepala adalah lebih baik dari pada satu. (Siberman, 1996 terjemahan Raisul Muttaqien, 2010: 163).

\section{Identifikasi Masalah}

Berdasarkan latar belakang masalah diatas maka permasalahan tersebut dapat di identifikasikan sebagai berikut:

1. Minat belajar siswa yang kurang dalam pembelajaran IPS Sejarah, yaitu kurang aktifnya siswa dalam proses pembelajaran.

2. Strategi yang digunakan guru pada umumnya menggunakan pembelajaran 
yang bersifat konvensional yang terpusat pada guru sehingga dalam pembelajarannya kurang menarik minat dan keaktifan siswa.

3. Prestasi belajar siswa dalam mata pelajaran IPS Sejarah masih rendah belum bisa mencapai KKM yaitu 60 .

\section{Rumusan Masalah}

Bertolak dari penjelasan latar belakang dan identifikasi masalah diatas maka rumusan masalah dalam penelitian ini adalah:

1. Bagaimanakah penerapan penggunaan strategi pembelajaran The Power Of Two dalam pembelajaran IPS Sejarah pada siswa kelas VIIB MTsN Kembangsawit tahun pelajaran 2010/2011?

2. Apakah dengan menggunakan strategi The Power Of Two dapat meningkatkan minat belajar IPS Sejarah pada siswa kelas VIIB MTsN Kembangsawit tahun pelajaran 2010/2011?

\section{Tujuan Penelitian}

Adapun tujuan dari penelitian ini adalah untuk mengetahui :

1. Penerapan penggunaan strategi pembelajaran The Power Of Two dalam pembelajaran IPS Sejarah pada siswa kelas VIIB MTsN Kembangsawit tahun pelajaran 2010/2011.

2. Peningkatan minat belajar IPS Sejarah dengan menggunakan strategi pembelajaran The Power Of Two pada siswa kelas VIIB MTsN Kembangsawit tahun pelajaran 2010/2011.

\section{Manfaat Penelitian}

Hasil penelitian ini diharapkan dapat memberikan manfaat bagi:
1. Peneliti

a. Sebagai salah satu persyaratan untuk menyelesaikan Sarjana Pendidikan Sejarah di IKIP PGRI Madiun.

b. Menambah pengetahuan serta pengalaman dalam meningkatkan kualitas pembelajaran mata pelajaran IPS Sejarah di MTsN Kembangsawit melalui strategi pembelajaran The Power Of Two.

2. Guru Sejarah

a. Memberikan referensi kepada para guru tentang strategi-strategi pembelajaran bervariasi.

b. Mendorong guru untuk menciptakan proses belajar mengajar yang bisa menumbuhkan ketertarikan siswa terhadap sejarah dengan strategi pembelajaran yang bervariasi dalam penyampaian materi.

3. MTsN Kembangsawit Kabupaten Madiun Memberikan referensi serta informasi kepada pihak sekolah tentang penerapan strategi pembelajaran yang bervariasi.

4. Siswa

a. Memberikan motivasi untuk meningkatkan minat belajarnya.

b. Mendorong siswa untuk berfikir aktif, kritis dalam memahami sejarah sehingga bisa meningkatkan hasil prestasi belajarnya.

\section{Kajian Pustaka}

\section{Pengertian Minat Belajar}

Minat adalah kecendrungan yang menetap untuk memperhatikan dan mengenang beberapa aktivitas. Syaiful Bahri Djamarah (2002:132). Slameto (2010:2) merumuskan pengertian belajar adalah suatu proses usaha yang dilakukan seseorang untuk memperoleh suatu perubahan tingkah laku yang baru secara keseluruhan, sebagai hasil pengalamannya 
sendiri dalam interaksi dengan lingkungannya.

Maka dapat disimpulkan bahwa minat belajar adalah kecendrungan atau ketertarikan seseorang untuk melakukan perubahan sehingga memperoleh peningkatan, baik dalam tingkah laku atau intelegensi dirinya tanpa ada yang menyuruhnya.

\section{Ciri-ciri Minat Belajar}

Ciri-ciri siswa yang memilikki minat belajar adalah mempunyai kecenderungan yang tetap untuk memperhatikan dan mengenang sesuatu yang dipelajari secara terus menerus, ada rasa suka dan senang pada sesuatu yang diminati, memperoleh suatu kebanggaan dan kepuasan pada sesuatu yang diminati. Ada rasa keterikatan pada sesuatu aktivitas-aktivitas yang diminatinya, lebih menyukai suatu hal yang menjadi minatnya daripada yang lainnya, dimanifestasikan melalui partisipasi pada aktivitas dan kegiatan.

\section{Pengertian Strategi Pembelajaran}

Menurut David (dalam Wina Sanjaya, 2008:126) dalam dunia pendidikan strategi diartikan sebagai a plan, method, or series of activities designed to achieves a particular educational goal. Jadi dengan demikian strategi pembelajaran dapat diartikan sebagai perencanaan yang berisi tentang rangkaian kegiatan yang didesain untuk mencapai tujuan pendidikan tertentu.

\section{Jenis-Jenis Strategi Pembelajaran}

Rowntree (1974 dalam Wina Sanjaya 2008:128-129) mengatakan bahwa ada beberapa strategi pembelajaran, diantaranya:

a) Strategi Penyampaian Penemuan atau Expositing

Dalam strategi expositing bahan pelajaran disajikan kepada siswa dalam bentuk jadi dan siswa dituntut untuk menguasai bahan tersebut. Roy Killen (dalam Wina Sanjaya 2008:128) menyebutnya dengan strategi pembelajaran langsung, dikatakan sebagai strategi pembelajaran langsung karena materi pembelajaran disajikan begitu saja kepada siswa, siswa tidak dituntut untuk mengolahnya. Kewajiban siswa adalah menguasainya secara penuh, dengan demikian dalam strategi ekspositori guru berfungsi sebagai penyampai informasi.

\section{b) Strategi Discovery}

Strategi discovery berbeda dengan strategi exposition, dalam strategi discovery bahan pelajaran dicari dan ditemukan sendiri oleh siswa melalui berbagai aktivitas, sehingga tugas guru lebih banyak sebagai fasilitator dan pembimbing bagi siswanya, karena sifatnya yang demikian strategi ini sering juga dinamakan strategi pembelajaran tidak langsung.

c) Strategi Pembelajaran Kelompok

Strategi pembelajaran secara kelompok dilakukan secara beregu, sekelompok siswa diajar oleh seorang atau beberapa orang guru. Bentuk belajar kelompok itu bisa dalam pembelajaran kelompok besar atau pembelajaran klasikal atau bisa juga siswa belajar dalam kelompok-kelompok kecil semacam buzz group. Strategi kelompok tidak memperhatikan kecepatan belajar individual semua siswa dianggap sama. Oleh karena itu belajar dalam kelompok dapat terjadi pada siswa yang memiliki kemampuan tinggi akan terhambat oleh siswa yang mempunyai kemampuan biasa-biasa saja, sebaliknya siswa yang kurang memiliki kemampuan kurang akan merasa tergusur oleh siswa yang mempunyai kemampuan tinggi.

d) Strategi Pembelajaran Individual

Strategi belajar individual dilakukan oleh siswa secara mandiri. Kecepatan, kelambatan dan keberhasilan pembelajaran siswa sangat ditentukan oleh kemampuan 
individual siswa yang bersangkutan. Bahkan pelajaran serta bagaimana mempelajarinya didesain untuk belajar sendiri. Contoh dari strategi pembelajaran ini adalah belajar melalui modul, atau belajar bahasa melalui kaset audio.

\section{Fungsi Strategi Pembelajaran}

Strategi pembelajaran sangat berguna, baik bagi guru maupun siswa. Made Wena (2009: 2-3)

1) Bagi guru

Strategi dapat dijadikan pedoman dan acuan bertindak yang sistematis dalam pelaksanaan pembelajaran.

2) Bagi siswa

Pengguna strategi pembelajaran dapat mempermudah proses belajar (mempermudah dan mempercepat memahami isi pembelajaran), karena setiap strategi pembelajaran dirancang untuk mempermudah proses belajar siswa.

\section{Strategi Pembelajaran The Power Of Two}

Strategi pembelajaran The Power Two merupakan salah satu metode pembelajaran dari cooperative learning. Strategi pembelajaran The Power Of Two atau kekuatan dua orang dalam praktiknya diawali dengan pengajuan beberapa pertanyaan oleh guru pada siswa dalam kelompok kecil yang terdiri dari 2 siswa. Dukungan sesama siswa dan keragaman pendapat, pengetahuan serta ketrampilan mereka akan membantu menjadikan belajar bersama sebagai bagian berharga dari iklim belajar di kelas siswa. Aktivitas ini digunakan untuk meningkatkan pembelajaran dan menegaskan manfaat dari sinergi, bahwa dua kepala adalah lebih baik dari pada satu. (Siberman, 1996 terjemahan Raisul Muttaqien, 2010:163).
Kelemahan dan Kelebihan Strategi Pembelajaran The Power Of Two sebagai berikut.

a. Kelemahan dari strategi pembelajaran The Power Of Two adalah:

1) Memerlukan waktu yang panjang untuk membandingkan jawabanjawaban siswa.

2) Suasana kelas yang ramai ketika siswa mencari pasangannya

3) Hanya dipakai dalam kelompok kecil

b. Kelebihan dari strategi pembelajaran The Power Of Two adalah:

1) Mengembangkan sikap menghargai pendapat orang lain

2) Merangsang kreativitas siswa dalam menemukan jawaban

3) Memperluas pengetahuan siswa

4) Mempererat rasa sosial antara siswa

\section{Pendidikan Sejarah}

Sejarah termasuk disiplin ilmu baik art maupun humaniora. Sedangkan kajian yang bersifat sinkronik menjadikan ilmu sejarah termasuk ke dalam ilmu sosial. Urgensi bahwa terdapat relevansi antara tantangan dan tanggapan (challenge and response) terhadap perubahan-perubahan yang multidimensional dalam menghadapi masa depan dengan mempelajari masa lampau adalah sebuah keharusan. Sejarah adalah wahana pendidikan tertua di Indonesia, baik dalam perkembangan pendidikan sebelum maupun sesudah kemerdekaan. Sejarah sebagai mata pelajaran telah diajarkan sejak masa penjajahan Belanda, dan siswa belajar sejarah Belanda dengan judul Geschiedenis van Vanderlands (Said Hamid Hasan dalam Soebijantoro, 2011:22)

Pengajaran sejarah seyogyanya tidak lagi terlalu menekankan pengajaran hafalan fakta serta afektif doktriner tetapi lebih sarat dengan latihan berpikir historis kritis analitis, dengan pendekatan baru ini siswa (terutama di jenjang-jenjang sekolah yang lebih tinggi) 
dibiasakan untuk melihat/menerima gambaran sejarah dengan logika historis kritis (tidak pasif), sehingga tidak harus selalu dituntun oleh guru (yang sering sudah terdistorsi pula) dalam memaknai berbagai peristiwa sejarah yang dipelajarinya.( I Gde Widja, 2002: 3-4)

\section{Kerangka Pemikiran}

Pelajaran Sejarah merupakan salah satu mata pelajaran IPS di SMP atau MTs, Sejarah adalah ilmu yang mengkaji manusia, terutama mengenai jejak-jejak yang ditinggalkanya, gagasan, tradisi serta perjuangannya menghadapi alam, dengan kata lain sejarah adalah suatu ilmu yang mempelajari manusia atau usaha keras manusia dalam menaklukkan dunia.

Pembelajaran sejarah disekolahsekolah identik dengan hafalan dan ceramah, dengan cara pembelajaran ini membuat banyak siswa yang merasa bosan dan tidak berminat untuk aktif dalam pembelajaran sejarah. Pada hakekatnya pembelajaran sejarah tidak hanya memberikan pengetahuan atau kejadian masa lalu saja, tetapi guru sejarah dapat dikatakan berhasil menyampaikan materi sejarah apabila guru tersebut telah berhasil menerapkan pendidikan moral dan rasa nasionalisme pada diri siswa, serta dapat memecahkan masalah yang ada pada diri siswa atau masyarakat dengan melihat sejarah kehidupan orang-orang yang terdahulu

Strategi pembelajaran The Power Of Two diharapkan dapat menarik minat serta keaktifan siswa dalam pembelajaran IPS sejarah sehingga dapat meningkatkan prestasi belajarnya, karena dengan strategi pembelajaran The Power Of Two siswa diajak untuk menyelesaikan suatu masalah dengan cara berdiskusi dengan pasangannya. Strategi pembelajaran The Power Of Two menekankan bahwa dua kekuatan itu lebih baik dari pada pada satu kekuatan atau satu orang. Adanya kekuatan dua orang dalam menyelesaikan permasalahan diharapkan bisa mempermudah pemahaman siswa tentang materi pembelajaran sehingga dengan strategi pembelajaran The Power Of Two dapat meningkatkan prestasi belajar IPS Sejarah siswa pada khususnya serta meningkatkan minat belajar siswa pada IPS Sejarah. Adapun bagan alur kerangka berfikir dalam penelitian ini sebagai berikut.

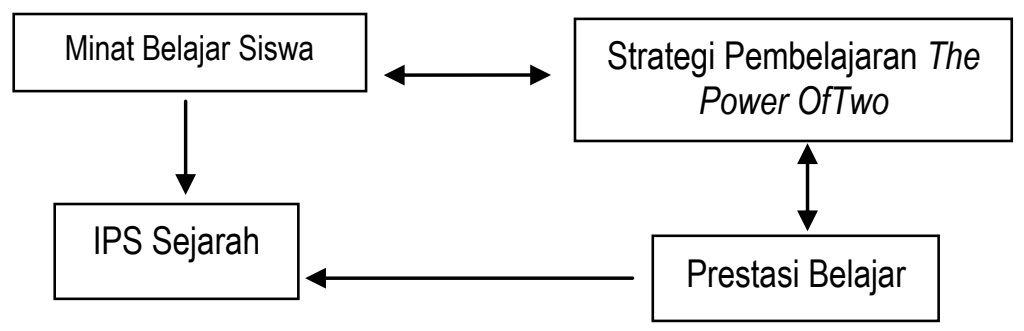

Bagan 1. Kerangka Pikir Penelitian

\section{Hipotesis Penelitian}

Berdasarkan kajian pustaka dan kerangka pemikiran, maka hipotesis tindakan dalam penelitian ini adalah strategi pembelajaran The Power Of Two dapat meningkatkan minat serta keaktifan dan prestasi belajar IPS Sejarah siswa kelas VIIB MTsN Kembangsawit Tahun Pelajaran 2010/2011. 


\section{Metodologi Penelitian}

\section{Tempat dan Waktu Penelitian}

Penelitian ini dilakukan di MTs Negeri Kembangsawit pada semester genap tahun pelajaran 2010/2011 selam 4 bulan.Subyek dari penelitian ini adalah siswa kelas VII B yang berjumlah 37 siswa terdiri dari 22 lakilaki dan 15 perempuan.

2. Prosedur Penelitian

Penelitian ini merupakan penelitian tindakan kelas (PTK) yang akan dilaksanakan dalam 2 siklus yang masingmasing siklus terdiri dari 4 tahapan (Suharsimi Arikunto, 2006:16) yaitu:

a. Perencanaan

Tahapan perencanaan merupakan tahapan awal yang diisi dengan merencanakan semua bahan ajar yang akan dipergunakan dalam penelitian. b. Pelaksanaan

Tahapan ini merupakan tahapan dimana dilaksanakannya semua rencana yang telah dipersiapkan dalam tahap perencanaan atau dengan kata lain adalah tahap penerapan pembelajaran.

c. Observasi

Tahapan ini guru bersama dengan observe mengopservasi seluruh aktifitas siswa dan guru dalam proses pembelajaran.

d. Refleksi/Evaluasi

Tahapan ini merupakan tahapan untuk mengevaluasi seluruh tindakantindakan yang telah dilakukan, dan setelah itu hasil evaluasi dijadikan patokan untuk tindakan atau siklus selanjutnya.

Adapun skema pelaksanaan kegiatan pada penelitian siklus I dan siklus II adalah sebagai berikut:

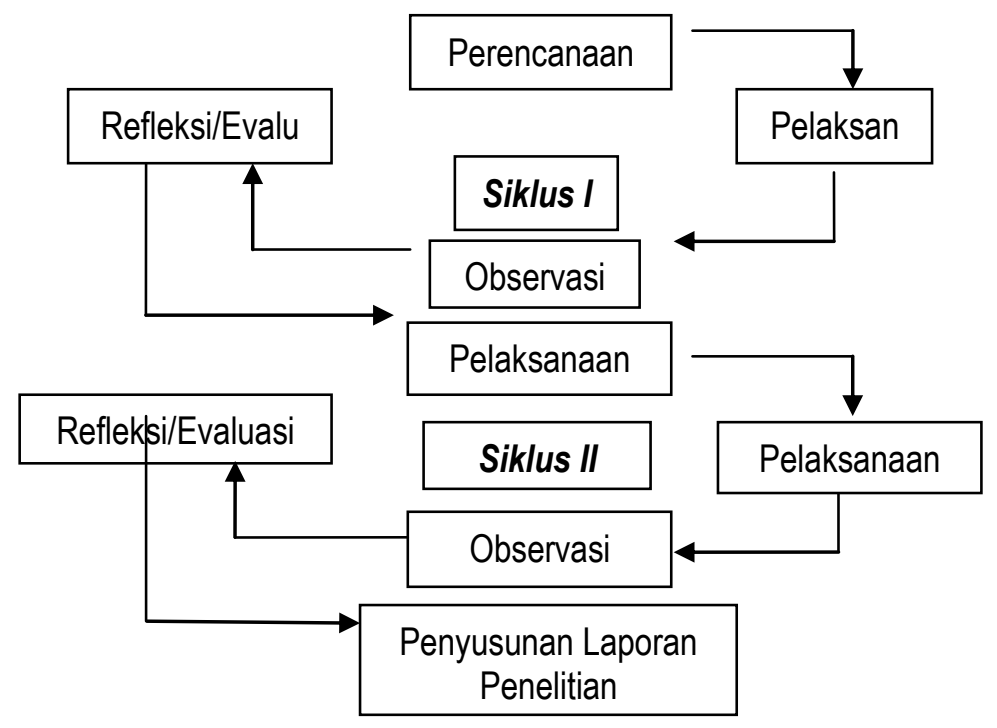

Bagan 2. Skema Kegiatan Penelitian (Suharsimi Arikunto, 2006:16) 


\section{Pengumpulan Data}

Adapun metode yang digunakan dalam pengumpulan data ini adalah sebagai berikut:

1. Observasi

Menurut Muhammad Burhan Bungin (2007:115) yang dimaksud dengan metode observasi adalah metode pengumpulan data yang digunakan untuk menghimpun data penelitian melalui pengamatan dan pengindraan.

\section{Angket}

Angket adalah sejumlah pertanyaan tertulis yang digunakan untuk memperoleh informasi dari responden. Dalam hal ini adalah laporan tentang pribadinya atau halhal yang diketahuinya. Acep Yoni (2010: 60) 3. Dokumentasi

Riduwan mengatakan bahwa dokumentasi adalah metode yang digunakan untuk memperoleh data langsung dari tempat penelitian, meliputi buku-buku yang relevan, peraturan-peraturan, laporan kegiatan, foto-foto, film dokumenter, data yang relevan penelitian.(2009:31)

\section{Analisis Data}

Data yang diperoleh dalam penelitian ini secara umum dianalisis melalui deskriptif kualitatif. Analisis data dilakukan pada tiap data yang dikumpulkan, baik data kuantitatif maupun data kualitatif.

\section{Data Observasi}

Data yang diperoleh pada lembar observasi kemudian dihitung presentasenya. Hasil analisis data observasi persiklus akan memberikan gambaran mengenai perkembangan keaktifan serta respon siswa setelah dilakukan pembelajaran dan selanjutnya digunakan untuk merencanakan tindakan pada siklus berikutnya. Pada penelitian ini, data hasil observasi yang diperoleh dianalisis dengan cara perhitungan sebagai berikut; jumlah skor yang diperoleh siswa dari 6 aspek yang diamati dibagi dengan jumlah maksimal dari seluruh aspek lalu dikalikan dengan nilai tertinggi dari kriteria presentase keaktifan siswa, atau dengan kata lain rumus presentasenya adalah sebagai berikut:

\section{$\sum$ skor yang diperoleh siswa}

Presentase keaktifan siswa $=$

$\sum$ skor maksimal $x 100 \%$

Sedangkan secara klasikal presentase keaktifan siswa di hitung delam rumus:

$\Sigma$ siswa yang sangat aktif

Presentase keaktifan siswa $=$

$\sum$ jumlah siswa $x 100 \%$

Data yang diperoleh dari observasi kegiatan guru juga dianalisis menggunakan rumus:

$$
\text { Presentase }=\frac{\sum \text { skor yang diperoleh }}{\sum \text { skor maksimal }} \times 100 \%
$$


Adapun kriteria yang akan dijadikan dasar untuk mengambil kesimpulan dari prosentase keaktifan siswa adalah:

$81-100 \%=$ sangat aktif

$61-80 \%=$ aktif

$41-60 \%=$ cukup aktif

$21-40 \%=$ kurang aktif

$0-20 \%=$ kurang aktif sekali (Suharsimi Arikunto, 2005:44)

\section{Data Angket}

Angket minat belajar siswa yang terdiri dari 10 butir pernyataan dengan rincian 6 pernyataan positif dan 4 butir pernyataan negatif, di uji validitas dan relabelitas

\section{a. Validitas}

Validitas angket ini menggunakan Korelasi Product Moment, yaitu dengan rumus:

$$
r x y=\frac{N \sum X Y-\left(\sum X\right)\left(\sum Y\right)}{\sqrt{\left(\sum X^{2}-\left(\sum X\right)^{2} N \sum Y^{2}-\left(\sum Y\right)^{2}\right.}}
$$

(Suharsimi Arikunto,2002:81)

Tabel 1.Hasil Validitas Soal Angket Minat Belajar Siswa

\begin{tabular}{|c|c|c|c|c|c|c|}
\hline $\begin{array}{c}\text { No } \\
\text { Soal }\end{array}$ & $\sum \mathbf{X}$ & $\left(\sum X\right)^{2}$ & $\sum X^{2}$ & $\sum \mathbf{X Y}$ & Nilai & Keterangan \\
\hline 1 & 103 & 10609 & 295 & 2850 & 1,126 & Valid \\
\hline 2 & 72 & 5184 & 158 & 1981 & 0,3933 & Valid \\
\hline 3 & 95 & 9025 & 257 & 2569 & 0,0546 & - \\
\hline 4 & 124 & 15376 & 438 & 3394 & 0,4052 & Valid \\
\hline 5 & 101 & 10201 & 339 & 2932 & 1,3208 & Valid \\
\hline 6 & 131 & 17161 & 491 & 3575 & 0,2803 & - \\
\hline 7 & 109 & 11881 & 337 & 2994 & 0,58 & Valid \\
\hline 8 & 108 & 11664 & 334 & 2976 & 0,6317 & Valid \\
\hline 9 & 85 & 7225 & 212 & 2343 & 0,5366 & Valid \\
\hline 10 & 74 & 5476 & 173 & 2087 & 0,8863 & Valid \\
\hline
\end{tabular}

\section{b. Reliabelitas}

Reliabel itu berhubungan dengan masalah kevalidan. Apabila hasilnya reliabel maka tes itu mempunyai kevalidan yang tinggi, untuk mengetahui tinggkat reliabel tes maka di gunakan rumus Koefisien Alpha

$$
\mathrm{S}^{2}=\frac{\sum X^{2}-\frac{\left(\sum X\right)^{2}}{N}}{N}
$$

(Suharsimi Arikunto, 2002:97)

Jumlah varian setiap soal menggunakan rumus 


$$
\sigma^{2}=\frac{\sum_{X} 2-\left(\frac{\sum X}{N}\right)^{2}}{N}
$$

Hasil dari seluruh varian setiap soal adalah 62,18

Jumlah seluruh varian lalu dimasukkan dalam rumus varian yaitu;

$$
\left(\Sigma \sigma_{i}^{2}\right)
$$

Hasil dari semua varian adalah 6,13 dan selanjutnya dimasukkan dalam rumus Alpha

$$
\text { yaitu } r_{11}=\left(\frac{n}{n-1}\right)\left(1-\frac{\sum \sigma^{2}}{\sigma_{t}^{2}}\right)
$$

Jadi hasil reliable dari angket ini adalah 1,001 adalah

Adapun rumus yang digunakan dalam mencari kriteria ketercapaian minat siswa

$$
M x=\frac{\Sigma f x}{N} \quad \text { dan } S D x^{0}=\sqrt[i]{\frac{\sum f\left(x^{2}\right)^{2}}{N}-\left[\frac{\sum f\left(x^{0}\right)}{N}\right]^{2}}
$$

1. Apabila jumlah skor yang diperoleh siswa lebih besar dari Mx $+\mathrm{SDx}$, yaitu $27,08+1,17$ $=28,25$ Maka apabila skor siswa lebih besar dari 28 dapat dikatakan minat belajarnya tinggi.

2. Apabila jumlah skor yang diperoleh siswa diantara $\mathrm{Mx}+\mathrm{SDx}$ dan $\mathrm{Mx}+\mathrm{SDx}$, yaitu 2628 dapat dikatakan minat belajarnya sedang.

3. Apabila jumlah skor yang diperoleh siswa kurang dari Mx - SDx', yaitu 27,08 - 1,17= 25,91.Maka apabila skor siswa kurang dari 26 dapat dikatakan minat belajarnya rendah.

Presentase minat belajar klasikal $=$

$$
\sum \text { siswa yang berminat tinggi }
$$

$$
\sum \text { jumlah siswa }
$$

$x 100 \%$

\section{Hasil Penelitian}

MTsN Kembangsawit berada di Jln.Raya Kebonsari tepatnya di desa Balerejo Kebonsari Madiun. Berdirinya MTsN Kembangsaawit tidak terlepas dari sejarah berdirinya Pondok Pesantren "Subulul Huda" Kembangsawit. MTsN Kembangsawit berdiri pada tahun 1968 dan kepala Madrasah yang sekarang menjabat adalah Suwono,S.Ag, disamping itu MTsN Kembangsawit terakreditasi dengan peringkat A pada tahun 2005.
Adapun visi yang dimiliki oleh MTs Negeri Kembangsawit adalah "Berkualitas dalam Imtaq, Berilmu, Berakhlaq dan Berbudaya" sedangkan misi MTs Negeri Kembangsawit adalah "Menciptakan Lembaga Pendidikan yang Islami dan berkualitas, menghasilkan lulusan madrasah yang berprestasi dalam berbagai bidang, selalu berpartisipasi aktif dalam syiar agama Islam, disiplin dalam kerja, mewujudkan manajemen kekeluargaan, kerjasama, pelayanan prima dengan meningkatkan silaturahmi" 
Pada penyelenggaraan pengajarannya, MTs Negeri Kembangsawit memiliki 18 ruang kelas yang terbagi menjadi 6 ruang kelas pada masing-masing jenjang kelas. Ditinjau dari segi sarana sebagai penunjang dalam proses pembelajar siswa MTs Negeri Kembangsawit memiliki 1 ruang laboratorium komputer sebagai penunjang mata pelajaran TIK (Teknologi Informasi dan Komunikasi) dan laboratorium bahasa.

MTs Negeri Kembangsawit memiliki fasilitas olahraga, yaitu 1 buah lapangan serba guna yang digunakan pula untuk volly, futsall, basket dan upacara bendera. Disisi

Selain kegiatan intrakurikuler, siswa juga mendapat kegiatan ekstrakurikuler seperti pramuka, pidato, olahraga, keterampilan menjahit, seni musik, olimpiade sains. Tenaga pengajar yang ada di MTs Negeri lain, terdapat pula sebuah ruang perpustakaan yang berfungsi sebagai tempat referensi atau sumber ilmu baca untuk para siswa dalam belajar serta terdapat pula 1 buah mushola, 1 koperasi sekolah, 2 buah kantin, ruang UKS, tata usaha, lab IPA, ruang BP untuk bimbingan Konseling serta sebuah areal tempat parkir untuk siswa. Perubahan tekhnologi yang semakin maju maka MTs Negeri Kembangsawit pun memilihi areal hotspot yang bisa di manfaatkan oleh seluruh siswa dan guru di MTs Negeri Kebangsawit.

Kembangsawit adalah guru-guru bidang studi yang semuanya mempunyai latar belakang pendidikan $\mathrm{S} 1$, adapun jumlah guru di MTs Negeri Kembangsawit adalah sebagai berikut:

Tabel 4.1 Data guru MTs Negeri Kembangsawit 2010/2011

\begin{tabular}{|c|c|c|c|c|c|c|}
\hline \multicolumn{6}{|c|}{ Jumlah dan Status } & \multirow{3}{*}{ Jml Total } \\
\hline \multicolumn{3}{|c|}{ Guru Tetap/PNS } & \multicolumn{3}{|c|}{ GTT/Non PNS } & \\
\hline $\mathrm{L}$ & $P$ & $\Sigma$ & $\mathrm{L}$ & $\mathrm{P}$ & $\Sigma$ & \\
\hline 23 & 12 & 35 & 2 & 1 & 3 & 38 \\
\hline
\end{tabular}

Sumber: Data internal MTs Negeri Kembangsawit

Adapun hasil penelitian dari data yang terkumpul adalah:

\section{Siklus I}

Pada proses pelaksanaan pada siklus I menunjukkan bahwa hasil dari ke- seluruhan siswa dari angket, observasi keaktifan siswa serta tes formatif yang telah dikerjakan siswa, dapat diperoleh hasil sebagai berikut:

Tabel 3. Hasil Penilaian pada siklus I

\begin{tabular}{|l|l|c|c|}
\hline No & \multicolumn{1}{|c|}{ Penilaian } & Presentase & Predikat \\
\hline 1 & Minat Belajar Siswa & $46 \%$ & Cukup Tinggi \\
\hline 2 & Keaktifan Siswa & $41 \%$ & Cukup Aktif \\
\hline 3 & Prestasi Belajar Siswa & $46 \%$ & Belum Tuntas \\
\hline 4 & Aktifitas Guru & $65 \%$ & Cukup Baik \\
\hline
\end{tabular}




\section{Siklus II}

Penerapan strategi pembelajaran The Power Of Two dalam proses pembelajaran IPS sejarah pada siswa kelas VII BMTs
Negeri Kembangsawit siklus II dapat dikatakan mengalami peningkatan, dapat disajikan dalam tabel:

Tabel 4. Hasil penilaian pada siklus II

\begin{tabular}{|l|l|c|c|}
\hline No & \multicolumn{1}{|c|}{ Penilaian } & Presentase & Predikat \\
\hline 1 & Minat Belajar Siswa & $92 \%$ & Sangat Tingi \\
\hline 2 & Keaktifan Siswa & $84 \%$ & Sangat Aktif \\
\hline 3 & Prestasi Belajar Siswa & $92 \%$ & Tuntas \\
\hline 4 & Aktifitas Guru & $95 \%$ & Baik Sekali \\
\hline
\end{tabular}

\section{Pembahasan}

Hasil peningkatan minat belajar, keaktifan serta prestasi belajar siswa selama proses pembelajaran IPS Sejarah dengan menggunakan strategi pembelajaran The Power Of Two dapat disajikan dalam diagram dibawah in :

\section{0 \\ 90 \\ 80 \\ 70 \\ 60 \\ 50 \\ 40 \\ 30 \\ 20 \\ 10 \\ 0}

Minat Keaktifan Prestasi Aktivitas

Gambar 1. Diagram Peningkatan Hasil Belajar

\section{Siklus I}

Pada dasarnya dapat dikatakan bahwa penerapan strategi pembelajaran IPS Sejarah dengan menggunakan strategi pembelajaran The Power of Two pada siswa kelas VIIB MTsN Kembangsawit minat belajar siswa pada siklus I dari 10 penyataan yang diberikan kepada siswa melalui angket memberikan hasil akhir sebesar $46 \%$ yang berarti memiliki minat cukup tinggi, tetapi hal ini belum mencapai target yang seharusnya yaitu $81 \%$ atau lebih. Pada siklus । 
menunjukkan bahwa dalam proses pembelajaran dengan menggunakan strategi pembelajaran The Power Of Two siswa belum terlalu aktif atau belum terlalu merespon apa yang telah diperintahkan guru, selain itu aktifitas guru selama proses pembelajaran juga mempengaruhi keadaan siswa selama pembelajaran. Hasil aktifitas guru pada siklus I menunjukkan bahwa perolehan skor guru sebesar $65 \%$ dari 10 aspek yang diamati, hal ini berarti guru belum optimal dalam pengajaranya sehingga hasil observasi keaktifan siswa dalam proses pembelajaran siklus I dari 6 aspek yang diamati secara klasikal mendapat $41 \%$.

Kurangnya minat serta keaktifan siswa selama proses pembelajaran menggunakan strategi pembelajaran The Power Two berdampak pula pada hasil prestasi belajarnya. Pemberian tugas individu yang berjumlah 5 soal uraian menunjukkan bahwa siswa yang memperoleh nilai $\geq 60$ sebanyak 17 siswa atau dengan presentase $46 \%$, sedangkan siswa yang memperoleh nilai $\leq 60$ sebanyak 20 anak atau dengan presentase $54 \%$. Hasil ini menunjukkan bahwa siswa kelas VII B MTs Negeri Kembangsawit belum mencapai ketuntasan.

\section{Siklus II}

Pada siklus II dari diagram diatas menunjukkan bahwa dari minat belajar, keaktifan serta prestasi siswa mengalami peningkatan. Pada proses pembelajaran siklus II siswa sudah mulai terbiasa dengan pembelajaran menggunakan strategi pembelajaran The Power of Two. Hasil analisis minat belajar siswa pada siklus II adalah $92 \%$, ini menunjukkan bahwa peningkatan minat belajar siswa secara keseluruhan sebesar $46 \%$.

Hasil analisis aktifitas guru pada proses pembelajaran siklus II adalah 95\%, maka dapat dikatakan bahwa secara garis besar guru telah melaksanakan proses pembelajaran secara optimal sehingga membuat siswa pun aktif dalam mengikuti pembelajaran IPS Sejarah menggunakan strategi pembelajaran The Power Of Two. Adapun hasil presentase keaktifan siswa pada siklus II adalah $84 \%$, ini mengalami peningkatan sebesar $43 \%$. Selain presentase yang mengalami peningkatan, respon siswa atau keaktifan siswa yang pada awalnya belum berani bertanya atau mengutarakan pendapatnya maka pada siklus II ini siswa berani bertanya dan selalu aktif ketika guru memberikan tugas atau pun memberikan penjelasan materi. Pada siklus II ini pun siswa aktif dalam kegiatan diskusi kelompok maupun diskusi kelas, siswa saling mengutarakan pendapat dan bertanya apabila belum jelas tentang penjelasan materi yang disampaikan oleh guru. Pada akhir pembelajaran siswa bersama-sama memberikan kesimpulan atas materi dan tugas yang diberikan guru, sehingga prestasi belajar siswa mengalami peningkatan, hasil analisis menunjukkan bahwa siswa yang memperoleh nilai $\geq 60 \%$ sebanyak 34 siswa atau sebaesar $92 \%$ dan siswa yang memperoleh nilai $\leq 60 \%$ sebanyak 3 siswa $8,1 \%$, maka dapat dijelaskan bahwa prestasi belajar siswa kelas VII B secara klasikal adalah tuntas.

Berdasarkan pembahasan diatas maka dapat dikatakan bahwa pembelajaran IPS Sejarah menggunakan strategi pembelajaran The Power Of Two pada siswa kelas VII B MTs Negeri Kembangsawit telah meningkatkan minat, keaktifan serta prestasi belajar siswa.

\section{Penutup}

\section{Simpulan}


Berdasarkan hasil penelitian dan pembahasan yang dikemukakan dalam $B A B$ IV, maka dapat disimpulkan bahwa penerapan strategi pembelajaran The Power Of Two dalam pembelajaran IPS Sejarah pada siswa kelas VIIB di MTsN Kemangsawit dapat diterima dengan baik serta dapat memotivasi siswa untuk aktif bertanya dan berpendapat dalam proses pembelajaran, sehingga siswa pun mengalami peningkatan dalam pemahaman materi, minat belajar dalam IPS Sejarah yang berdampak pula pada peningkatan prestasi belajarnya.

Strategi pembelajaran The Power Of Two dapat meningkatkan minat belajar serta keaktifan dan prestasi belajar IPS Sejarah siswa kelas VIIB MTsN Kembangsawit Tahun Pelajaran 2010/2011. Hal ini dapat dilihat dari presentase angket minat belajar siswa pada siklus I sebesar $46 \%$ dan mengalami peningkatan pada siklus II menjadi $92 \%$, sedangkan presentase keaktifan siswa pada siklus I adalah $41 \%$ meningkat pada siklus II menjadi $84 \%$ begitu pula prestasi belajar siswa meningkat pada pra siklus adalah $35 \%$ dan pada siklus I sebesar $46 \%$ lalu mengalami peningkatan pada siklus II menjadi $92 \%$. Adapun aktifitas guru selama proses pembelajaran menggunakan strategi pembelajaran The Power Of Two pada mata pelajaran IPS Sejarah yang telah di observasi pada siklus I jumlah skor yang diperoleh sebesar 26 (65\%), dan pada siklus II skor yang diperoleh sebesar $38(95 \%)$.

\section{Saran}

Sebagai umpan balik agar minat serta keaktifan belajar siswa meningkat dan berpengaruh pada prestasi belajarnya, adapun saran yang perlu disampaikan terkait penerapan strategi pembelajaran The Power Of Two dalam pelajaran adalah:
Pada dasarnya siswa aktif dalam proses pembelajaran yang bervariasi, sehingga diharapkan kepada sekolah agar memberikan penataran atau pelatihan tentang metode atau strategi pembelajaran yang bervariasi kepada guru-guru. Sehingga guru tidak menggunakan strategi pembelajaran yang konvensional yang hanya akan membuat siswa bosan dan tidak aktif dalam pembelajaran.

\section{Guru Mata Pelajaran IPS Sejarah \\ Guru diharapkan menggunakan} reverensi untuk materi pelajaran tidak hanya dari buku paket atau LKS, tetapi sebaiknya juga menggunakan reverensi dari internet atau buku-buku yang relevan.

\section{Sekolah}


Acep Yoni. 2010. Menyusun Penelitian Tindakan Kelas. Yogyakarta: Familia

Burhan Bungin.2007. Penelitian Kualitatif Komunikasi, Ekonomi, Kebijakan Publik, dan IImu Sosial Lainnya. Jakarta: Kencana Prenada Media Group

I Gde Widja. 2002. Menuju Wajah Baru Pendidikan Sejarah.Yogyakarta: Lappera Pustaka Utama

Kochhar terjemah Purwanta, Yovita Hardiwati. 2008. Pembelajaran Sejarah Teaching of History. Jakarta: Grasindo

Made Wena. 2010. Strategi Pembelajaran Inovatif Kontemporer Suatu Tinjauan Konseptul Operasional. Jakarta: Bumi Aksara

Muhibbin Syah.1999. Psikologi Belajar. Jakarta: Logos Wacana IImu

Riduwan. 2009. Skala Pengukuran VariabelVariabel Penelitian. Bandung: Alfabet

Siberman. 1996 terjemah Raisul Muttaqien. 2010. Active Learning 101 Cara Belajar Siswa Aktif. Bandung: Nusamedia dan Nuansa

Slameto. 2010. Belajar \& Faktor-Faktor yang mempengaruhi .Jakarta: Rineka Cipta

Soebijantoro. 2011. "Peran Pendidikan Sejarah Dalam Pengembangan Pembelajaran Multikultural Di LPTK". Agastya Jurnal
Pendidikan Sejarah, vol 1, № 1, Januari 2011. Hal 22

Suharsimi Arikunto, 2002. Dasar-Dasar Evaluasi Pendidikan. Jakarta. Bumi Aksara , 2005. Manajemen Penelitian. Jakarta: Rineka Cipta Suhardjono, dan Supardi.2006. Penelitian Tindakan Kelas.Jakarta: Bumi Aksara

Syaiful Bahri Djamarah. 2002. Psikologi Belajar. Jakarta: Rineka Ciptai

Wina Sanjaya. 2008. Strategi Pembelajaran Berorientasi Standar Proses Pendidikan. Jakarta: Kencana 